\title{
Greenhouse heating by using an installation of biomass gasification
}

\author{
Evelin Laza ${ }^{1 *}$, Liliana Dumitrescu ${ }^{2}$, Madalina Boboc ${ }^{3}$ and Georgiana Moiceanu ${ }^{4}$ \\ ${ }^{1}$ INMA Bucharest -Timisoara Branch, Romania \\ ${ }^{2}$ INOE 2000-IHB Bucharest, Romania \\ ${ }^{3}$ INCDPM Bucharest, Romania \\ ${ }^{4}$ UP Bucharest, Romania
}

\begin{abstract}
The use of renewable energies has seen a significant increase in energy demand in agriculture, in competition with solid, liquid or gaseous fossil fuels. Wood and other forms of biomass including energy crops, agricultural and forest biomass are transformed into energy through thermal, biological or physical processes. Thermo-chemical conversion, biomass gasification, is the most attractive technology that offers a high conversion efficiency compared to direct burning or rapid pyrolysis.
\end{abstract}

\section{Introduction}

Generator gas, called gas, can be used directly for thermal applications: cooking machines and heating installations, where changes have been made to ensure an optimal combustion air excess, and after proper filtration at the generation of electricity by feeding internal combustion engines, Stirling engines, or in the perspective of combustion cells[1,2,3,4].

The gasification of the biomass produces a generator gas with an average calorific value of $5 \mathrm{MJ} / \mathrm{Nm}^{3}$, with a power conversion of the wood mass in the $70-85 \%$ range, is at least 3 times more efficient than direct combustion. Conversion efficiency depends on: the design gas-generator solution, the composition, dimensions and humidity of the fuel, as well as the generator operating load $[1,4,5]$. Air conditioning of greenhouses, heating and ventilation is an essential condition for achieving economically efficient production but is requiring large-scale installations at the same cost, which has made it more and more abandoned. At present, traditional systems with trunking networks that occupy a lot of space, make it hard for operators and little mechanization, contain a great deal of metal and cost a lot. Obviously, this system has advantages in terms of high heat inertia, heating and radiation, high operating safety and lower maintenance personnel [1].

The main issue with regard to the fuel used for heating greenhouses is that of the price on which production costs depend. The second is the level of pollution. Combustion fossil fuels increase the concentration of $\mathrm{CO}_{2}$ in the earth's atmosphere, spill into the environment particles of smoke, $\mathrm{NO}_{\mathrm{x}}$ and uncharged hydrocarbons that all contribute to increased

\footnotetext{
* Corresponding author: eveline anda@yahoo.com
} 
environmental pollution. The smallest pollution is obtained when gaseous fuels are consumed and combustion is controlled to reduce as much as possible the production of pollutants [1].

Most small and medium greenhouses cannot benefit from methane gas, LPG or diesel, but more often CLU and fuel oil, are much cheaper. Combustion of CLU or naphtha is done with the release of pollutants and requires hot or steam heating systems that are expensive as investment and maintenance $[1,2]$.

As an alternative to these energy sources in the last decade, it is found that the energy produced from the gasification of wood or agricultural biomass is increasingly used in rural thermal applications where there is a sufficient amount of gas-based biomass at a cost of use to reduce $[1,2,3]$.

Taking into account the seasonality of greenhouse heating, the heat source needs a very small initial investment or outside of the greenhouse season to be used in other applications to lower the share of the investment's depreciation $[1,3,4]$.

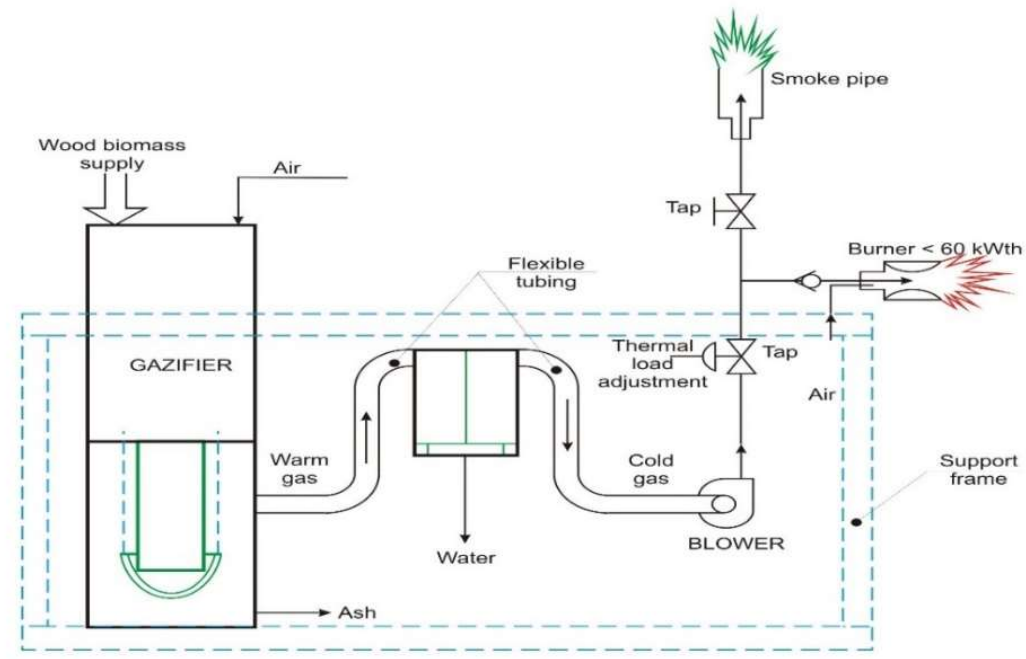

Fig. 1. Sketch of the heating system with producer gas.

\section{Methodology}

In the cold mixing chamber, a mixture of a recirculated air flow from the inside and an outside air flow is made. It is located at the bottom, at ground level, and consists of external air intake valves mounted on the outside wall and recirculated air intake valves mounted inside the greenhouse. The recirculated air / outside air ratio is controlled by the simultaneous actuation and the actuator that receives a command signal from the automatic steering system.

The gas-fired burner, specially designed for combustion of low calorific gases, is supplied with a gaseous flow rate at a pressure of 6 to 20 mbar adjusted with the regulating valve and a pre-heating combustion air flow rate that is regulated with a flap.

The heating agent is guided into a polyethylene tube stretched across the greenhouse and hanging in the ceiling. The tube has clamp-shaped cutouts that distribute hot air in the form of jets oriented so as to wash the exterior walls and achieve good mixing with the greenhouse air to smooth the temperature inside. The side walls of the greenhouse, are provided with the exhaust flow, equal to the outside air flow introduced into the greenhouse. The self-closing flaps are adjusted to maintain an overpressure in the 
greenhouse in the $20 \ldots 60$ mbar range, depending on the construction of the greenhouse and the current crop.

The biomass was transported to the location of use, where it was stored in a covered enclosure to dry naturally to $10-20 \%$ relative humidity. For gasification, the biomass was minced to the size of $1-5 \mathrm{~cm}$ and the hopper loaded and unloaded it to the top of the gas generator until it reached the upper level measured with a capacitive level transducer that outputs a signal. The supply was done sequentially, with constant operating periods, to increase the durability of the conveyor [6-13].

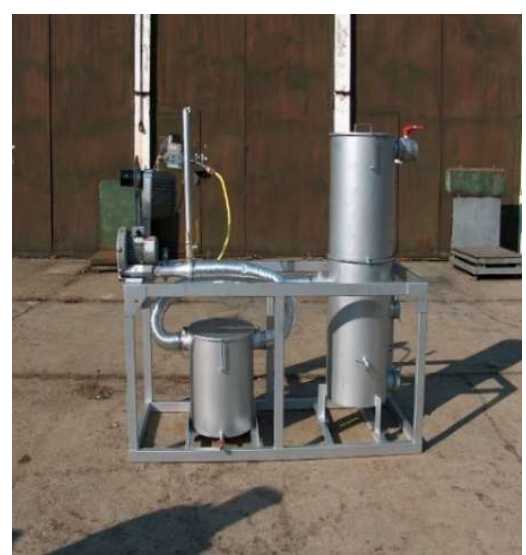

Fig. 2. Overview of the producer gas heating system

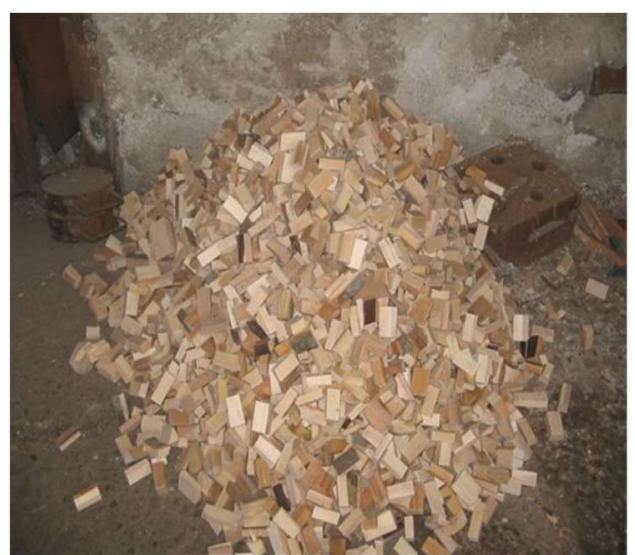

Fig. 3. Biomass material used for testing
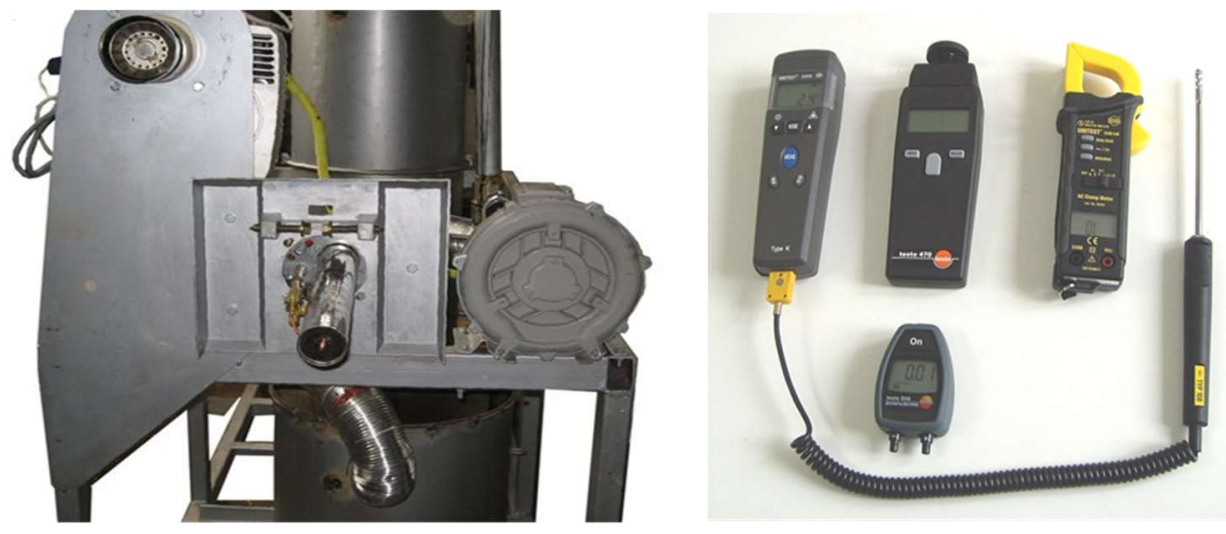

Fig. 4. Front view of the producer gas heating system Fig. 5. Apparatus used for testing
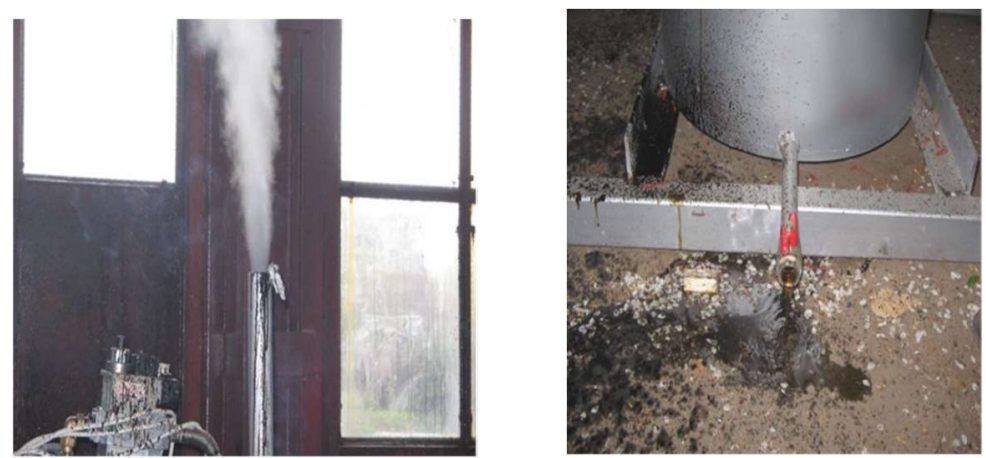
Fig. 6. Evaporation of condensate from the producer gas generator

To start the fire in the gasifier, the blower was used to create an air-sucking airflow through the biomass from the fuel tank. When the wood gas leaves the gasification unit, all the oxygen pressed down with the air through the fire tube was chemically modified and contained carbon monoxide $(\mathrm{CO})$ and water $\left(\mathrm{H}_{2} \mathrm{O}\right)$. Wood gas can not burn unless combined with a correct amount of oxygen. The tightness of the gas burner unit is absolutely essential.

Ideally, while wood gas enters the burner, it must be mixed with air in a 1: 1 or 1.1: 1 ratio (air to gas) in volume.

The fire tube is filled with coke up to $100 \mathrm{~mm}$ above the grid. The fuel tank is filled with dry woody biomass, the lid is closed and fully open the air valve.

For the determination of the kinematic, technological and electric parameters (power voltage, current absorbed by electric motors) the following tools were used:

Table 1. Instrument or apparatus used

\begin{tabular}{|c|c|c|}
\hline No.crt. & The name of the instrument or apparatus & Range of measurement \\
\hline 1 & Metal roulette & $0 \div 2 \mathrm{~m}$ \\
\hline 2 & Callipers $200 \times 0,1$ & $0 \div 200 \mathrm{~mm}$ \\
\hline 3 & Callipers with deepth $200 \times 0,1$ & $0 \div 200 \mathrm{~mm}$ \\
\hline 4 & Gradient scale & $0 \div 500 \mathrm{~mm}$ \\
\hline 5 & Chronometer & $\begin{array}{l}\text { - minutes } \\
\text { - seconds }\end{array}$ \\
\hline 6 & Laboratory balance & - \\
\hline 7 & BENQ digital camera & - \\
\hline 8 & Sound Level Meter Type 2237 B vibrometer & $30 \div 140 \mathrm{~dB}$ \\
\hline 9 & Technical thermometer with solid capillary & $-20 \div+30^{\circ} \mathrm{C}$ \\
\hline 10 & $\begin{array}{l}\text { Differential electronic manometer } \\
\text { type TESTO } 506\end{array}$ & $\begin{array}{c}0 \div 1 \mathrm{mbar} \\
1 \div 10 \mathrm{mbar} \\
10 \div 200 \mathrm{mbar}\end{array}$ \\
\hline 11 & MICRODUST PRO digital dust detector & $0,001 \div 2.500 \mathrm{mg} / \mathrm{m}^{3}$ \\
\hline 12 & $\begin{array}{l}\text { Digital TESTOTERM } 4000 \text { Air Flow Meter, } \\
\text { Temperature and Flow Meter (Testovent) }\end{array}$ & $\begin{array}{c}0,4 \div 40 \mathrm{~m} / \mathrm{s} \\
-120 \div+1.300{ }^{\circ} \mathrm{C} \\
10 \div 500.000 \mathrm{~m}^{3} / \mathrm{h}\end{array}$ \\
\hline 13 & $\begin{array}{l}\text { Digital apparatus for measuring electrical } \\
\text { parameters type UNITEST CHB } 140\end{array}$ & $\begin{array}{c}0 \div 400 \mathrm{~A} \\
0 \div 600 \mathrm{Vc} . \mathrm{a} . \\
0 \div 400 \Omega\end{array}$ \\
\hline 14 & $\begin{array}{l}\text { Digital thermometer with laser type UNITEST } \\
94009,\end{array}$ & $\begin{array}{c}-50^{\circ} \mathrm{C} \div 0^{\circ} \mathrm{C} \\
0^{\circ} \mathrm{C} \div+200^{\circ} \mathrm{C} \\
+200^{\mathrm{C}} \div+1.333^{\circ} \mathrm{C}\end{array}$ \\
\hline 15 & Gas analyzer Code 99F20006 Tempest 50 & $\mathrm{O}_{2} / \mathrm{CO} / \mathrm{NO}$ \\
\hline
\end{tabular}

The general behavior of the gasifier heating system was observed and the determination of the production capacity and the quality of the combustion operation in order to determine the optimal technological parameters for the design of a $50 \mathrm{kWth}$ producer gas heating system.

For this purpose, within the limit of the quantity of product available for testing, weighing $150 \mathrm{~kg}$ biomass waste of oak, european beech (fagus) and fir, with a moisture content of less than $20 \%$ of the pieces with a length between $20 \div 50 \mathrm{~mm}$ were weighed for the preparation of ten batch of gasifier and one gaseous filter batch [11-13].

The products corresponding to a batch were manually loaded into the fuel tank, the fire tube, the gasifier grid and the gas filter, the blower started, and then passed the primary coke production cycle into the. Next, after $10 \div 15$ minutes, during the normal gas 
production phase (attempted by igniting the exhaust gas to the tube), the burner of the installation is switched on.

The flow of gas produced by the gasifier has been determined based on the measurements after the filter and gas-producing are recorded in the following table:

Table 2. The flow of gas produced by the gasifier

\begin{tabular}{|c|c|c|c|c|c|}
\hline \multirow{2}{*}{$\begin{array}{c}\text { No. } \\
\text { crt. }\end{array}$} & \multirow{2}{*}{ The measured feature } & \multirow{2}{*}{ M.U. } & \multicolumn{3}{|c|}{ The measured value } \\
\cline { 4 - 6 } & & $\mathrm{I}$ & $\mathrm{II}$ & III \\
\hline 1. & The gas velocity & $\mathrm{m} / \mathrm{s}$ & 0,5 & 0,9 & 2,09 \\
\hline 2. & Diameter of pipeline & $\mathrm{mm}$ & 90 & 90 & 90 \\
\hline 3. & The rate flow of produced gas & $\mathrm{Nm}^{3} / \mathrm{h}$ & 9,1 & 18,3 & 48 \\
\hline
\end{tabular}

The burned gas flow rate produced by the gasification system was determined on the basis of the measurements after the burner are recorded in the following table:

Table 3. The burned gas flow rate produced by the gasification system

\begin{tabular}{|c|c|c|c|c|c|}
\hline \multirow{2}{*}{$\begin{array}{l}\text { No. } \\
\text { crt. }\end{array}$} & $\begin{array}{c}\text { Measured or calculated } \\
\text { feature }\end{array}$ & \multirow{2}{*}{ M.U } & \multicolumn{3}{|c|}{ The measured value } \\
\cline { 4 - 6 } & & I & II & III \\
\hline 1. & Speed of gas burned & $\mathrm{m} / \mathrm{s}$ & 0,5 & 0,8 & 2,09 \\
\hline 2. & Diameter of pipeline & $\mathrm{mm}$ & 180 & 180 & 180 \\
\hline 3. & The gas flow burned & $\mathrm{m} / \mathrm{h}$ & 36 & 72 & 188 \\
\hline
\end{tabular}

The lower calorific value of the producer gas was determined on the basis of the chemical composition of the gas at the different biomass components are recorded in the following table:

Table 4. The lower calorific value of the producer gas

\begin{tabular}{|c|c|c|c|c|c|c|c|}
\hline \multicolumn{7}{|c|}{ Chemical composition of gas in \% } & $\begin{array}{c}\text { Inferior } \\
\text { heat } \\
\text { power. } \\
\mathbf{k c a l} / \mathbf{~ m}^{\mathbf{3}}\end{array}$ \\
\hline Wood Biomass & $\mathbf{C O}$ & $\mathbf{H}$ & $\mathbf{C H}_{\mathbf{4}}$ & $\mathbf{C}_{\mathbf{n}} \mathbf{H}_{\mathbf{2 n}}$ & $\mathbf{C O}_{\mathbf{2}}$ & $\mathbf{N}_{\mathbf{2}}$ & \\
\hline Dry oak & 17,8 & 15,9 & 3,2 & 0,4 & 16,1 & - & 1296 \\
\hline Dry beech & 18,4 & 16,5 & 3,1 & 0,5 & 15,1 & 48,3 & 1321 \\
\hline Wry fir & 16,1 & 18,1 & 2,2 & 0,8 & 15,7 & 56,1 & 969 \\
\hline Charcoal brown briquettes & 32,2 & 7,3 & 2,8 & - & 2,6 & 57,1 & 1363 \\
\hline
\end{tabular}

Biomass mass flow rate $(\mathrm{kg} / \mathrm{h})$, determined by weighing, was between 20 (Beech) and 22 (Fir) $\mathrm{kg} / \mathrm{h}$ so on average $21 \mathrm{~kg} / \mathrm{h}$. It results in a specific biomass consumption of $21 \mathrm{~kg}$ / h: $60 \mathrm{~kW}$ ht $/ \mathrm{h})=0.35\left(\mathrm{~kg} / \mathrm{kW}_{\mathrm{ht}}\right)$.

The duration of the normal operating cycle was timed and was between 10 and 15 minutes.

The pressure drop through the gasifier, $\Delta_{\mathrm{p} 1}\left[\mathrm{~mm} \mathrm{H}_{2} \mathrm{O}\right]$ were determinated by measuring the depressions before and after the gasifier being in the limits of $30 \ldots 50 \mathrm{~mm} \mathrm{H}_{2} \mathrm{O}$ so an average of $40 \mathrm{~mm} \mathrm{H}_{2} \mathrm{O}$.

The pressure drop through the filter, $\Delta_{\mathrm{p} 2}\left[\mathrm{mmH}_{2} \mathrm{O}\right]$ were determined by measuring the depressions before and after the gasifier being in the limits of $15 \ldots 25 \mathrm{~mm} \mathrm{H}_{2} \mathrm{O}$, an average of $20 \mathrm{~mm} \mathrm{H}_{2} \mathrm{O}$.

The temperature of the producer gas at the outlet of the gasifier was determined with the gas velocity in the specially designated locations using the TESTOTERM 4000 (Testovent) digital speedometer, temperature and air flow meter and was around $80^{\circ} \mathrm{C}$. 
The producer gas temperature at the filter outlet was determined with the same apparatus at the specially designated locations of the filter and was around $35^{\circ} \mathrm{C}$. The producer gas temperature at the burner inlet was determined under similar conditions and was around $28^{\circ} \mathrm{C}$.

\section{CONCLUSIONS}

There is required legislative and organizational measures to reduce pollution and emission of greenhouse gases and dependence on crude oil imports more expensive and uncertain about oil being a source of exhaustion.

A solution is the use of biomass resources for the production of solid fuel, liquid fuel and gas. The use of biomass for the production of heat by gasification has the advantage of using a renewable energy resource that does not increase the concentration of $\mathrm{CO}_{2}$ in the earth's atmosphere. The use of biomass for heating greenhouses has the advantage of reducing production costs.

Applying low energy efficient technologies, allowing long-term industrial plants to operate, will help reduce the cost of heating greenhouses all year round.

As a result of those presented above it can be seen that the heating of greenhouses with relatively cheap energy produced from the thermo - chemical gasification of wood or agricultural biomass is an economic solution for small and medium - sized greenhouses located in areas with high potential for gas - biomass collection.

\section{Acknowledgement}

This work was supported by a grant of the Romanian Research and Innovation Ministry, through Programme 1 - Development of the national research-development system, subprogramme 1.2 - Institutional performance - Projects for financing excellence in RDI, contract no. 16PFE.

\section{References}

1. A. Romanek, Local Greenhouse Biomass Heating System, AGRAL Program, INMA Bucharest, (2004)

2. Europeean Comission Directorat-General for Energy (DG XVII), Combustion and Gasification of Agricultural Biomass - Technologies and Applications, Thermie Program Action BM 40, CEEETA-PRATEX, Lisabona, (1995)

3. H.E.M. Stassen, Knoef, Small Scale Gasification Systems, Biomass Technology Group BV, Olanda, (1997)

4. Ministry of Energy and Environment, Wood for Energy Production, TechnologyEnvironment-Economy, Center for Biomass Technology, Denmark, Report, pp.54-59, (1999),

5. R. Sims, J. Gigler, The Brilliance of Bioenergy Small project using biomass. Renewable Energy World, Vol. 5, Nr. 1, pag. 57-63, (2002).

6. I. Voicea, Gh. Voicu, P. Cardei, V. Vlăduţ, S. Biriş, A Mathematical Model of Chopped Miscanthus Briquetting Process, The $8^{\text {th }}$ International Conference INTER-ENG 2014 Interdisciplinarity in Engineering, 9 - 10 October 2014, "Petru Maior" University of Tîrgu Mureş Romania, Procedia Technology (19), ISSN: 2212-0173, pages 750-757, (2015)

7. I. Voicea, V. Vlăduț, P. Cârdei, M. Matache, I. Găgeanu, Gh. Voicu, C. Popescu, G. Paraschiv, O. Kabas, Compacting process and mathematical analysis of miscanthus briquettes expansion, Proceedings of the $\mathbf{4 3}^{\text {th }}$ International Symposium on Agricultural 
Engineering "Actual Tasks on Agricultural Engineering", Opatija - Croatia, ISSN 13332651 , pag. $667 \div 676,(2015)$

8. M. Chiţoiu, Gh. Voicu, G. Paraschiv, G. Moiceanu, V. Vlăduţ, M. Matache, E. Marin, G. Bunduchi, A. Danciu, I. Voicea, I. Găgeanu, Energy consumption of a hammer mill when chopping miscanthus stalks, Proceedings of the $\mathbf{4 4}^{\text {th }}$ International Symposium on Agricultural Engineering "Actual Tasks on Agricultural Engineering", Opatija - Croatia, pag. $215 \div 224$, (2016)

9. M. Chiţoiu, Gh. Voicu, G. Paraschiv, G. Moiceanu, V. Vlăduţ, M. Matache, I. Grigore, G. Bunduchi, I. Voicea, I. Găgeanu, Comparison of energy consumption of a hammer mill during chopping miscanthus stalks and energetic willow, Proceedings of the $\mathbf{4 5}^{\text {th }}$ International Symposium on Agricultural Engineering "Actual Tasks on Agricultural

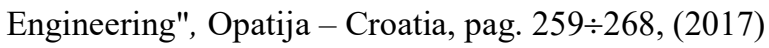

10. I. Găgeanu, Gh. Voicu, V. Vlăduţ, I. Voicea, Experimental research on the influence of recipes used on the quality of biomass pellets, $\mathbf{1 6}^{\text {th }}$ International Scientific Conference "ENGINEERING FOR RURAL DEVELOPMENT", pag. 785-791, (2017)

11. G. Moiceanu, M. Chiţoiu, Gh. Voicu, Gh. Paraschiv, V. Vlăduţ, I. Găgeanu, M. Dincă, Comparison between miscanthus and willow energy consumption during grinding, Proceedings of the $\mathbf{4 6}^{\text {th }}$ International Symposium on Agricultural Engineering "Actual Tasks on Agricultural Engineering", Opatija - Croaţia, pag. $369 \div 378$, (2018)

12. N. Ungureanu, V. Vlădut, Gh. Voicu, M. Dincă, B. Zăbavă, Influence of biomass moisture content on pellet properties - review, $17^{\text {th }}$ International Scientific Conference "Engineering for Rural Development", Jelgava, Latvia, pag. 1876-1883, (2018)

13. G. Moiceanu, Gh. Voicu, Gh. Paraschiv, V. Vlăduţ, P. Cârdei, M. Dincă, Relationships analysis between the grinding parameters of Miscanthus giganteus stalks using a hammer mill, Proceedings of the $\mathbf{4 7}^{\text {th }}$ International Symposium on Agricultural Engineering "Actual Tasks on Agricultural Engineering", Opatija - Croatia, ISSN 1333-2651, pag. 399-408, (2019). 